\title{
1
}

\section{The Australian embassy in Washington}

\author{
David Lowe, David Lee and Carl Bridge
}

The year 2015 marked the 75th anniversary of Australian diplomatic representation in Washington. It also marked the end of one era and the start of a new one for the current embassy building on Massachusetts Avenue on Scott Circle, which is being demolished and rebuilt in order to meet expanded needs. The current embassy building has served Australians since 1969. While the milestone of 75 years of Australian representation in Washington passed quietly, the rich history of prominent Australians, including some of our best-known ambassadors, working at the coalface of Australia-US relations warrants more investigation than there has been to date. This study aims to address this omission.

Without overburdening the construction metaphor, the theme of substantial rebuilding while strengthening Australia's presence and range of diplomatic endeavours sets an appropriate tone for the trajectory of this book. From humble beginnings when RG Casey arrived to found the legation in 1940 (in a large house on Cleveland Avenue) with a modest staff of five, to today, when the embassy boasts more than 250 personnel, marks a spectacular rise in the Australian presence. Yet neither the increased numbers nor an implied sense of steady growth in people-to-people contact between Australians and influential Americans will do by way of telling the full and complex story of Australia's representation. 
The legation set up in 1940 laid the foundations for one of Australia's longest functioning posts. Having established an Australian High Commission in London and appointed the first high commissioner (Sir George Reid) at the beginning of 1910, Australian governments waited 30 years before establishing any other overseas posts. Washington was one of three set up in 1940, the others being Ottawa and Tokyo. The period 1940 to 2015 saw extraordinary changes in the modes of communication between nations, the types of personnel who contribute to diplomacy, and the volumes of politicians, visitors and others drawing on embassy resources and time. One of the tasks of this book is to assess the significance of such changes as they played out in relation to particular Australian ambassadors in Washington and particular diplomatic episodes of note.

Similarly, the expectations and performances of different ambassadors over time is a constant thread. Ambassadors work to expectations different from those attached to the leaders of governments. The bestknown early 'diplomatic' encounter between Australia and the US, the testy negotiations between Australian Prime Minister William Morris Hughes (best remembered as 'Billy' Hughes) and US President Woodrow Wilson in Paris at the end of World War I, is therefore unhelpful even if it makes for compelling reading. Hughes clashed noisily with Wilson, whose attempts to undermine European control over colonies and inform the peacemaking with liberal internationalist principles met resistance from others in addition to Hughes; but, given Hughes's penchant for colourful metaphor and cutting riposte, it is not surprising that he attracted attention for his behaviour. In the eyes of some observers, Hughes brought something of the Anzac legend to the conduct of Australian diplomacy in 1919, punching above his weight, heedless of recognised forms of authority, and informed by a strident, self-interested brand of nationalism. To others, including members of the Australian delegation, he was more noisy than compelling, and he hardly set a diplomatic standard for US-Australia relations. ${ }^{1}$

If there is such a thing as an 'ideal' Australian Ambassador to the United States, what are the characteristics most needed? Such a question invites consideration of both generic attributes - those that make for an ideal

1 See Carl Bridge, William Hughes: Australia, Haus Histories, London, 2011. 
ambassador abroad - and particular attributes that lend themselves to service in the US. Among the generic qualities listed by Joan Beaumont in her analysis of Australian diplomats serving overseas up to 1969 were:

integrity, intelligence, negotiating skills. The ability to win the trust of foreign governments and leaders in the wider community, sociability, cultural sensitivity, a willingness to acquire an understanding of the political and historical background of other countries, and of course, diplomacy itself - tact and adroitness in personal relationships. ${ }^{2}$

The qualities of the ideal diplomat have attracted special attention from scholars for the period leading up to our starting point of 1940, on account of diplomats' prominence in the interwar years, but also for their inability to prevent war, and the suggestion that this was the beginning of decline for an elite group that had hitherto successfully managed international relations at some remove from both national leaders and their populaces. World War II then marked a temporary sidelining of professional diplomats as heads of government and their advisers dominated wartime summits; and, beyond 1945, the start of a new era of increased air travel and telecommunications logically meant that postwar governments grew less dependent on ambassadors overseas.

This snapshot of diplomatic change is analysed in rich detail, and through multiple case studies, in two well-known collections of essays led by Gordon Craig, The Diplomats, 1919-1939, and The Diplomats, 1939-1979. ${ }^{3}$ The earlier volume focused on Europe and the US, with one chapter on Japan, and the second volume incorporated more of Asia and the Middle East. Australia, as well as Canada, Africa and Latin America, appeared in neither. Otherwise, the most notable difference between the two volumes was the shift in the second towards political leaders as primary agents. Reviewers generally found the second volume less satisfactory than the first for, to summarise the main lines of criticism, in acknowledging the power shift away from the diplomat in international relations towards political leaders and the democratisation of foreign policy (including a greater role for public opinion), the second volume

2 Joan Beaumont, Christopher Waters, David Lowe, with Garry Woodard, Ministers, Mandarins and Diplomats: Australian Foreign Policy Making, 1941-1969, Melbourne University Press, Melbourne, 2003, p. 162.

3 Gordon Craig and Felix Gilbert (eds), The Diplomats: 1919-1939, Atheneum, New York, 1963; and Gordon Craig and Francis Loewenheim (eds), The Diplomats, 1939-1979, Princeton University Press, Princeton, 1994. 
loses a sense of how we might measure success in diplomats' work. ${ }^{4}$ Just as the authors analyse a new era in which professional diplomats seem to matter less, so too, according to reviewers, does their analytical lens begin to lose its focus.

Australian overseas diplomacy, excepting the High Commission in London, was thus born into a time of transition for the profession - and the start of a diplomatic era that historians have subsequently found less easy to judge. As a starting point, however, we can note several features about Australia's overseas posts and about the American embassy in particular. Clearly, the infancy of Australia's diplomatic corps and some persistent budget constraints around equipping overseas posts made for growing pains. At the level of popular imagination, the ambassador abroad continued to evoke glamour and status, high society and travel, but the reality was different. Although the memoir of Alan Renouf, long-serving professional diplomat and Australian Ambassador to the US (1977-79), is titled The Champagne Trail, its contents feature housing problems and stresses on family life more than depictions of the high life. ${ }^{5}$ While housing conditions have generally changed for the better since the times of these reflections, there appear also to be some strong constants. In 2003, Allan Gyngell and Michael Wesley concluded that, for all the advances in communications, the performance of Australian diplomats overseas still turned on their skills relating to information, reporting and advocacy. In response to a survey Gyngell and Wesley conducted in 2001, Australian diplomats liked to think that there was an Australian style of diplomacy, and that this was characterised by behaviour that was energetic, informal, direct, imaginative and well-prepared. ${ }^{6}$

Renouf is also one of the few diplomats to have offered, in his reflections on diplomacy and Australian foreign policy, extended thoughts on the most desirable attributes for an Australian Ambassador in Washington. In summary, he felt that a combination of those qualities demonstrated by Percy Spender (1951-58) and his successor Howard Beale (1958-64) constituted an ideal profile for an Australian Ambassador to the US: Spender was the extrovert and forceful personality, tough and intelligent

4 For reviews, see Arthur Schlesinger Jr, "The Measure of Diplomacy: What makes a Strategy grand?', Foreign Affairs, vol. 73, no. 4, 1994, pp. 146-51; Smith Simpson, 'The Diplomats, 1939-1979', Virginia Quarterly Review, vol. 71, no. 4, 1995, pp. 755-58.

5 Alan Renouf, The Champagne Trail: Experiences of a Diplomat, Sun Books, Melbourne, 1980.

6 Allan Gyngell and Michael Wesley, Making Australian Foreign Policy, Cambridge University Press, Cambridge, 2003, pp. 126-31. 
and an Australian nationalist; and Beale was the consummate networker, well-known and liked in Washington's social circles while also shrewd and strategic in his socialising. ${ }^{7}$ Renouf reached this opinion in the late 1970s. Since then, others have offered additional views. Jeremy Hearder, whose analysis of James Plimsoll's time as Ambassador to the US (1970-74) appears in this volume, writes:

Being ambassador in Washington is a more than usually demanding post. Always the hot breath of Canberra, wanting high level representations made; or awaiting instant, penetrating assessments about so many current issues. A very large staff to manage, a volume of daily business, and probably the heaviest social round - closely connected to the job. Related to this is the heavy round of high level visitors from home, and the importance of arranging for them suitable programmes, including meals at the Residence with key Americans who are in great demand to attend such functions.

The ambassador also needs to travel widely in the USA, to get a feeling for the nuances of this huge and varied country outside of the Washington Beltway, to explain Australian views as widely as possible; working closely with our consulate-generals and trade commissions, of which Australia probably has more in the USA than it does in any other country. And such travel is now all the more vital in an age when Congress plays an increasingly influential role in Washington. For instance, Senators and Representatives can be expected to respond better to an ambassador who has some first-hand acquaintance with their home states. Further it is almost essential to be knowledgeable about American history, and preferable to have worked or studied in another part of the country.

All in all, a strong constitution, boundless energy and endless curiosity are important anywhere, but especially in Washington. ${ }^{8}$

And finally, by way of advice for Australia's recent appointment as Ambassador to the US, Joe Hockey, former Ambassador John McCarthy (1995-97) penned some thoughts publicly, among which he urged Hockey to: read deeply and continuously, and show interest in the diversity that underpins US society; be sensitive to the time constraints under which US politicians and policy staff work, and not be offended by having to meet with junior staffers; see politicians when they are out of office and in their home states, away from Washington, which also

7 Ibid., p. 78.

8 Jeremy Hearder, 'Ideal Ambassador', unpublished essay, 13 April 2016, pp. 2-3. 
means travelling; ask for advice to keep up with the complex nature of changing policy considerations; treat embassy staff as professionals and recognise their skills; and recognise that Australia's security interests and those of the US may not always be the same. ${ }^{9}$

There are some common themes running through these analyses and recommendations, some of which resemble extensions of those more generic skills identified by Beaumont, Gyngell and Wesley. But between the desirable generic attributes and those especially appropriate for Washington also lie qualities of energy and scale. Being able to manage networks of connection on a scale not seen at most other posts, while hosting a seemingly continuous flow of important Australian visitors and leading a large embassy team, are among the most notable of requirements. Similarly, high levels of intellectual and physical energy are needed in order to keep up with the cascade of information relating to politics and policy considerations and changes in Washington while ensuring, at the same time, that adequate attention is paid to the states beyond the District of Columbia and New York, and that the full diversity of the US is appreciated. And the need to be resolute and possibly even forceful in advancing distinctively Australian interests is the other distinguishing characteristic. Logically, this should go without saying for all heads of overseas missions, but the suggestion by those with the greatest experience is that this is especially needed in Washington, where Australian and US security interests, in particular, can readily be conflated. The chapters that follow pay attention to these 'special' Washington factors of scale, energy, personal relationships leading to influence and the opening of doors, and judicious assertion of Australian interests in their analyses of ambassadors' performances.

While growing in size and reach, it is not the case that Australia's embassy in Washington has remained completely under the public radar. The embassy, along with the High Commission in London, has occasionally been in the public eye for reasons varying from important security and trade issues in Australia's relations with those key countries to speculation and rumours surrounding likely appointees. Australian governments, both Labor and Coalition, have repeatedly rewarded former politicians with the London and Washington posts - but not to the exclusion of senior career diplomats who have increasingly entered

9 John McCarthy, 'From One Ambassador to Another: Good luck if you go to Washington, Joe', The Drum, 23 September 2015, www.abc.net.au/news/2015-09-23/mccarthy-from-oneambassador-to-another/6796964. 
the tale. Public interest in the people and work of the Washington embassy may in the past have been too often led by gossip columns and fitful in occurrence, so a thorough historical analysis is well overdue. In this context too then, the need for reflection on and analysis of the embassy's work is apparent, and the embassy's 75th anniversary is a suitable occasion on which to perform this task.

With support from the Australian Department of Foreign Affairs and Trade, a group of experts on Australia in world affairs and Australia-US relations gathered at Deakin University's Waterfront campus in Geelong in October 2014 to examine the thickening ties, crises and changing priorities as experienced by Australia's ambassadors and leading diplomats in Washington during this period. Their analyses, bearing the fruits of original research and benefiting from having tested ideas among colleagues, make up this volume. They are organised as chapters, mostly according to an ambassador's term in Washington, but complemented by overviews where incumbents were short-term or to cater for topics of special interest.

From the outset, the chapters that follow had this consolidated volume in mind. They chart several trends in Australia's overseas policy that continue to be debated today. They consider the American security alliance in the context of World War II, the Cold War and in the post9/11 era; the distinctive social-cultural milieu in which Australians operate in Washington; the rise of the US Congress as a focal point for embassy work; the changing composition of representatives and tasks according to trade, intelligence and defence considerations; the crisis moments caused by Cold War and conflict in Southeast Asia and by independently minded Australian prime ministers such as Whitlam; and the particular interpersonal relationships, positive and otherwise, that shaped ambassadors' tenures.

We do not cover here in detail the 'pre-history' of official representation prior to 1940. This was significant and led by successive trade commissioners from 1918 to 1930, before the Great Depression hit, and then again from 1938 when Lewis Macgregor restored the line by heading the New York office. The role of trade commissioners continued to be important, and their number expanded after 1940, but we are fortunate that Boris Schedvin has provided much of this story 
in his history of the Australian trade commissioner service. ${ }^{10}$ Similarly, a forthcoming illustrated study of the Australian Embassy Residence in Washington by Christine Wallace and others will complement this volume.

The chapters here benefit from the input of past and present Australian representatives who have served in the embassy in Washington. A feature of the gathering in October 2014 was the presence of former Australian diplomats who worked in the embassy between the $1980 \mathrm{~s}$ and recent times. They agreed to participate in a witness seminar, expertly facilitated by award-winning journalist Jim Middleton, himself a frequenter of Washington in the 1980s and more recently. The witness seminar is a particularly specialised form of oral history, wherein several people associated with a particular set of circumstances or events are invited to meet together to discuss, debate, and even disagree about their reminiscences. Originally developed by the Institute of Contemporary British History in London in the 1980s, this program established that policymakers, both politicians and civil servants, could and should talk to academics on the record and in public. This engagement consequently marked a cultural sea change in the relationship between policymakers and scholars, and helped to consolidate the principle of open government.

The British have led the way in witness seminars, including a series run in conjunction with the Foreign and Commonwealth Office recalling the activities of overseas embassies and high commissions, and particular episodes such as the Falklands War and the fall of the Berlin Wall. ${ }^{11}$ The event held at Deakin in 2014 took its cue from this run of successful events in Britain, and also from the publication in 2010 of a history of Australia's High Commissioners in London that drew partly on witness testimony. ${ }^{12}$ The first part of the event featured former members of the Australian Department of Foreign Affairs (and Trade from 1987) and former members of the Australian Armed Forces who served in the Washington embassy in conversation with Jim Middleton and each other; and then answering questions from the floor. These recollections

10 Boris Schedvin, Emissaries of Trade: A History of the Australian Trade Commissioner Service, Austrade and the Australian Department of Foreign Affairs and Trade, Commonwealth Government of Australia, Canberra, 2008, pp. 21-24 and 66-68 for commissioners prior to 1940.

11 See, for example, Michael D Kandiah (ed.), The History, Role and Functions of the British High Commission in Canberra, Foreign \& Commonwealth Office, London, 2013, issuu.com/fcohistorians/ docs/Canberra_witness_seminar/13.

12 Carl Bridge, Frank Bongiorno and David Lee (eds), The High Commissioners: Australia's Representatives in the United Kingdom, 1910-2010, WHH Publishing, Canberra, 2010. 
and exchanges were recorded and formed the basis of an agreed transcript, now available online to complement this book. ${ }^{13}$ And the views expressed in the witness seminar also informed the subsequent academic presentations and chapters making up this volume.

The structure of this book takes its cue from the decisions and events behind the establishment and subsequent growth of Australia's diplomatic representation in Washington. Impending world war in 1939, with its attendant threats in the Pacific, led Joseph Lyons' Government to decide finally, after years of requests from the American side, to establish a diplomatic legation in Washington. In due course, Lyons' successor as prime minister, Robert Menzies, chose a senior Cabinet colleague with diplomatic experience in London, Richard Casey, to be Australia's founding minister to Washington, and Casey presented his credentials to President Roosevelt in February 1940. Casey was succeeded during the war by two other very distinguished Australians, Sir Owen Dixon, a High Court judge, and Sir Frederic Eggleston, longtime Chairman of the Commonwealth Grants Commission, whose experience of diplomacy stretched back to Versailles and who had been Minister to China. As Carl Bridge points out in his chapter, Casey was a model diplomat, establishing Australia and its concerns in the American public mind by means of a successful publicity campaign, while at the same time winning the confidence of Roosevelt and his inner circle, and networking brilliantly among the American military, administration, and in the business and media worlds. Casey actively and most effectively paved the way for Australia's wartime alliance with the US, looking to America strategically well in advance of Prime Minister John Curtin's more famous 'Look' in the wake of the Japanese attack on Pearl Harbor. Dixon, though a more diffident man and lacking Casey's political nous, mastered the intricacies of wartime supply at the height of the Pacific War, and was trusted implicitly by the Americans. Eggleston, arriving at the tail end of the war and literally too immobile for effective diplomacy in that frenetic period, was eclipsed by Minister for External Affairs Dr Herbert Vere Evatt's mercurial brilliance at the San Francisco conference that established the UN, but nevertheless proved a shrewd and energetic analyst of American politics and policy.

13 Available at: blogs.deakin.edu.au/contemporary-history-studies/witness-seminars/. 
The first Australian to be appointed as an ambassador, marking the postwar upgrade from legation, was Norman Makin, former Labor politician. Makin occupied the post for four-and-a-half years from 1946 to 1951, and worked hard in constrained circumstances to build a solid foundation and reputation among Washington's diplomatic corps. As Frank Bongiorno outlines in his chapter on Makin, some of the constraints he faced were resources - in the aftermath of the war, a dollar shortage and competing needs for the Chifley Government made for very tight circumstances in new embassy. Some of the constraints related to his minister, still Evatt, who would alternate between sharp criticism of embassy staff and extraordinary demands on their time. Another source of constraint was Makin's own reluctance to immerse himself either in the bigger issues of diplomacy joining the Australians and Americans or the whirl of the Washington cocktail circuit, which he despised. Despite what, at first glance, would appear to be very unpropitious set of circumstances for a new ambassador, Bongiorno suggests that Makin was effective in warding off the excesses of a rampaging Evatt, and Makin's integrity, kindness and Methodist values struck a good note with many, both within the embassy and in Washington.

Makin was followed by an ambassador who was almost an exact opposite. Percy Spender, Australia's longest-serving Ambassador to the US, from 1951 to 1958, arrived there without seeming to relinquish his former role as Minister for External Affairs. He determinedly built up the embassy in size and reputation, and thrust himself into most of the big issues of the day, often without waiting for direction from Canberra. These issues included the attempt to expand the remit and consultative and committee activity around the new Australia, New Zealand, United States Security Treaty (ANZUS), and an increasingly testing environment in the UN as more of the decolonising world joined as members. And, in the eyes of many policymakers, the Cold War took root in Asia, with communist-led challenges in Korea and then French Vietnam causing special concern for the US establishment. Spender saw the early to mid-1950s as a pivotal time in which Australia needed to demonstrate its credentials as an alliance partner with the Americans, and he fretted on the consequences of not being in the right circle when some of the biggest strategic decisions would be made. Given that his term saw the successful testing of US and Russian hydrogen bombs, and serious discussion of the use of atomic weapons in Vietnam, his alarm was hardly exaggerated. His attentiveness to big issues and his success in gaining access to high circles also reflected how hard and 
effectively he worked. But, as David Lowe suggests in his chapter on the Spender period, there was another more psychological-social dimension to Spender's behaviour. This gregarious man who, with his wife Jean, fitted well into the Washington social set and befriended several highranking Americans, including the Dulles brothers, feared being 'on the outer' and what that might mean for Australia - to the extent that it coloured his ambassadorship more than has been appreciated.

Spender's successor, another Menzies Government political appointee in Howard Beale, also enjoyed strong relationships with Washington's policymaking elite. In his chapter, Matthew Jordan analyses Beale's sixyear tenure from 1958, a period that saw him locked in testing exchanges about the level of Australia's preparedness to act under the Southeast Asia Treaty Organization in defence of Laos against communist-led challenges, and about the remit of the ANZUS Treaty at the time of Indonesia's incorporation of West New Guinea and then Konfrontasi aimed the newly formed Malaysia. Beale worked hard and effectively in representing Canberra's views and in reporting back the messages emerging from his engagements with President Kennedy and leading members of the State and Defense departments. He initially succeeded in encouraging US thinking about the operability of ANZUS in an indirect way that involved Australia's commitments to Malaya/Malaysia: Australian commitments to countering the Cold War struggle against communism in Southeast Asia could be considered in the context of supporting Malaya/Malaysia, and hence an ally of the US was pulling its weight. But this equation was hard to sustain in the face of minimal Australian defence spending and the need for the Americans to think flexibly in order not to push Indonesia's President Sukarno into the communist camp; and, like his colleagues in Canberra, Beale struggled to make a bigger positive mark in the US-Australia security relationship.

In a case study from the early 1960s, Chris Waters invites us to consider the embassy's engagement with policy-making. He analyses the work of the four-power Study Group convened in Washington in 1962 to examine future trends and development in the colonial territories of the South Pacific. The group comprised the United States, Britain, Australia and New Zealand, and arose from both the general quickening of pace in the dismantling of overseas empires and a recommendation from an ANZUS meeting. Comprised of talented diplomats, the Study Group soon roamed beyond its initial fact-gathering and problem-identification towards policy suggestions. As Waters shows, while Minister for 
External Affairs Garfield Barwick was happy with its conclusions, and with Australia's allies' interest in the region, the Menzies Cabinet reacted severely to the Study Group's report. Paul Hasluck, Minister for the Territories, led the counter-action, incensed at the suggestion that Cabinet's policy direction could be set by a group of officials meeting in Washington. The Australian Cabinet watered down the significance of the report, but was not successful in marginalising it in bureaucratic circles. Waters argues that the Study Group's main recommendations did, in fact, serve as important guidelines for Australian officials for the remainder of the decade. The episode highlighted the growing role of diplomats as experts who could help shape Australia's foreign policy.

The first career diplomat to be appointed to the Washington embassy, Keith Waller, was renowned for his tact and insight, and was a logical appointee. Despite this, he arrived by default. He was chosen only after Menzies had searched hard among his ministers and had concluded that none were suitable. Waller served in Washington from 1964 to 1970. He spent unusually long hours with President Lyndon B Johnson, mostly by accompanying Ed Clark, Johnson's appointed Ambassador to Australia and an adviser he relied on for counsel, to visit the President. Despite this, as Peter Edwards shows in his chapter, Waller was not able to exercise any particularly decisive influence in Washington beyond dropping into conversation with other American officials his easy access to the White House. Early in his tenure, the issue that had exercised his predecessors, namely the imprecise safeguards that ANZUS might offer in the event of clashes with Indonesia, did not clarify markedly. The Harold Holt-Johnson relationship was a strong one, but too brief, and the escalation of both American and Australian commitments of ground troops in Vietnam enmeshed the fortunes of the two allies, but not with any sense that Canberra would be kept informed of US strategic thinking. When Richard Nixon became President at the beginning of 1969, this lack of consultation grew sharper; but by this time deteriorating relationships within the Coalition Government in Canberra also made life difficult for an Australian Ambassador in Washington, and Waller was glad to leave to become Secretary of the Department of External Affairs.

The election in December 1972 of the first Labor administration since 1949, as Jeremy Hearder demonstrates, ushered in three of the most turbulent years in the history of the Australian-American relationship. Two of Australia's most experienced diplomats helped the Australian 
Government to navigate this first ANZUS crisis in the period from December 1972 to November 1975. These were a former Permanent Secretary of the Department of Foreign Affairs, Sir James Plimsoll, and another of Australia's most experienced diplomats, Sir Patrick Shaw.

Shaw had been both Ambassador to Indonesia and Permanent Representative to the UN, New York. Plimsoll's extraordinary standing as a diplomat and the range of his contacts in America helped smooth the substantial rift that developed in Australian-American relations over matters such as US policies on the conflict in Indochina. As the first of David Lee's two chapters shows, Shaw, who took up his posting in Washington in 1974, played a similar role to Plimsoll in robustly representing his government while at the same time seeking to maintain cordial relations with the US. After two years of what must have been one of his most challenging postings, he died of a heart attack in December 1975.

From 1975 to 1983 the Liberal-National Country Party Government led by Malcolm Fraser moved to strengthen the Australia-US relationship, resisting the efforts by US Democrat President Jimmy Carter to demilitarise the Indian Ocean and seeking to widen the scope of the ANZUS alliance to extend to the Indian Ocean. Reflecting the status of the post of Ambassador to the US was that its occupants were former permanent secretaries of the Department of Foreign Affairs: Alan Renouf from 1977 to 1979 and Sir Nicholas Parkinson, who served from 1976 to 1977 and again from 1979 to 1982. The embassy in Washington during this period helped the Fraser Government handle an issue that would loom as extremely divisive in the 1980s: visits to Australia and New Zealand by US naval vessels that might be nuclearpowered or be carrying nuclear weapons.

When in 1982 the leader of the opposition, Bill Hayden, appeared to equivocate on whether a future Labor administration would continue to permit such ship visits, Prime Minister Malcolm Fraser moved to exploit the Australian Labor Party's (ALP) weakness on the AustraliaUS alliance in the same way as Robert Menzies had done in 1963 over Labor's attitude to the North West Cape naval base. The subject of David Lee's second chapter is the role of the embassy in Washington in helping the Hawke Government deal with two crises in the AustraliaUS relationship in the 1980s. The first was the crisis within the ANZUS alliance precipitated by the New Zealand Labour Government's implementation in 1984 of its platform to refuse entry to nuclear-armed 
or nuclear-powered vessels. The second was brought on by the US Government's decision in 1985 to subsidise agricultural exports to the detriment of Australian primary producers.

Leading the Australian embassy in Washington during this time of crisis was one political appointment and one career diplomat. Sir Robert Cotton was the first political appointment to the position since Beale. Cotton was a Liberal senator from New South Wales who had held senior portfolios in the Gorton, McMahon and Fraser governments and then the position of Consul-General in New York. Appointed to Washington by Malcolm Fraser in 1982, Cotton was gladly retained by Labor Prime Minister Bob Hawke. Hawke, in so doing, was anxious to reassure President Ronald Reagan and his Cabinet of the essentially bipartisan character of Australian policy towards the US. In 1983 Hawke and his Minister for Foreign Affairs, Bill Hayden, brokered a compromise by which the government would continue to support US ship visits to Australia while also introducing a package of measures aimed at promoting the reduction of the nuclear arms race and the establishment of a nuclear-free zone in the South Pacific. This modus vivendi in the ALP, however, was strained in 1984 with the election of a New Zealand Labour Government. The ANZUS crisis of 1984 and 1985 was more serious than the contretemps between Whitlam and President Nixon between 1972 and 1974 because it led, in the end, to the dissolution of the tripartite ANZUS alliance that had been in place since 1951. The embassy, however, helped the Australian Government to soften the effect of the rupture on Australia by persuading the US to leave the ANZUS Treaty intact as an umbrella to govern the alliance relationship between Australia and the US, including regular bilateral meetings between the two nations that became known as AusMin.

But no sooner had the ANZUS crisis been settled when another major crisis developed over US trade and economic policy, namely the US decision to subsidise agricultural exports as part of its trade war with the European Economic Community. The Ambassador from 1985 to 1989 was the experienced career diplomat, Rawdon Dalrymple. A major focus of the embassy under Dalrymple's leadership was the lobbying of the administration and, increasingly, Congress, to mitigate the effect of US trade and economic policy on efficient Australian exporters. In both the ANZUS crisis from 1984 to 1986 and the economic disputes from 1985 onward, the embassy was an important means of communication between the Australian and the US Government and Congress. 
The embassy was, however, not the only mode of communication. The US embassy in Canberra was an important conduit and, increasingly, prime ministers conducted their own diplomacy by telephone - or sometimes by way of special emissary, as Plimsoll had found during the Whitlam years.

James Cotton argues in his chapter that Australia's foreign relations in the 1990s may be viewed as beginning in 1989 with the destruction of the Berlin Wall and the collapse of communism in Eastern Europe, and ending with the terrorist attacks in the US in 2001. The ending of the Cold War coincided with a major focus by the Australian Government on Australia's increasingly important economic relationship with Northeast Asia and its political relationship with Southeast Asia. The Hawke Government's launching of Asia-Pacific Economic Cooperation (APEC) in 1989, Cotton argues, may be seen as being designed to help prepare Australia for a diminishing US economic impact on Australia. But although APEC was at first conceived without the US as a member, an APEC including the US became the centrepiece of Prime Minister Paul Keating's plans for regional enmeshment. Keating's proposal for a conclave of regional heads of government was ably supported by his Ambassador to the US, Don Russell, a former Keating staffer. Cotton shows how Russell followed a tradition, pioneered by Casey, of seeking to address many constituencies in America but focusing on economic issues in contrast with Casey's main priority of encouraging a military alliance with the British Empire and, through it, Australia. This reflected Keating's conviction that Australia's relationship with the US was entering a phase in which trade and economic issues would play as important a role as security issues. The embassy continued to have a full trade and economic agenda following the change of government in 1996. Under the Howard Government, the embassy in Washington would play a critical role in helping it successfully conclude a Free Trade Agreement with the US. But notwithstanding the increasing focus on Asia in the 1990s, security issues remained important. The Hawke Government made a military commitment to the Gulf War in 1991 supported by Russell's predecessor as Ambassador to the US, Michael Cook. After the election of a Coalition Government in 1996, Australian Ambassadors John McCarthy and Andrew Peacock supported the Howard Government's desire to upgrade the security aspects of the relationship. The increasing salience of security issues culminated 
in 2001 when Peacock's successor, Michael Thawley, was instrumental in advising the Howard Government to invoke the ANZUS Treaty in response to the terrorist attacks on the US in 2001.

The editors decided not to give detailed historical treatment to the last three Ambassadors to the United States, Dennis Richardson (2005-2009), Kim Beazley (2010-2016) and the current head of mission, Joe Hockey (2016- ). Beazley, however, has contributed to the volume in the form of reflections by the outgoing Australian Ambassador to the US. More detailed analyses of these last three ambassadorships await the elapse of further time and the opening of primary historical records under the Archives Act 1983, which will see records from 2005 and after become available in the period from 2025 onward. The historical records relating to the current Ambassador, Joe Hockey, will be open to the public around the time of the centenary of the establishment of the Australian legation in Washington in 2040.

In lieu of detailed treatment, the next section of the introduction offers a brief analysis of the last three Ambassadors to the United States. They included one career public servant and two political appointees. The career public servant, Dennis James Richardson, was born in Kempsey in 1947 and educated at the University of Sydney. He joined the Department of External Affairs in 1969 as a graduate, becoming a member of a remarkable cohort that included Allan Gyngell, Sandy Hollway, Ric Smith, Bill Farmer and John Dauth. These men and Richardson all went on to become heads of agencies and to occupy senior diplomatic positions.

Richardson was posted to Nairobi between 1969 and 1971 and to Port Moresby from 1975 to 1977 . He then served between 1982 and 1985 as Counsellor in the Australian embassy, Jakarta, under Rawdon Dalrymple, who would himself go on to head the embassy in Washington in the second half of the 1980s. After diplomatic service in Indonesia, Richardson was promoted to the position of Assistant Secretary in the Department of Immigration and Multicultural and Ethnic Affairs, where he served in 1986 and 1987. He then transferred to the Department of the Prime Minister and Cabinet and was promoted to head its International Division between 1988 and 1990. Richardson was subsequently principal foreign affairs adviser in the last years of Bob Hawke's prime ministership in 1990 and 1991. After Paul Keating's replacement of Hawke as Prime Minister, Richardson returned as a Deputy Secretary to the Department of Immigration and Multicultural 
Affairs from 1993 to 1996. With the change of government in Australia in 1996, Prime Minister John Howard appointed Richardson to head the Australian Security Intelligence Organisation (ASIO), a post he held until he was appointed Ambassador to the US in 2005. By that time, after terrorist attacks on US soil in 2001 and terrorist bombings in Bali in the following year, issues of intelligence and security were an increasingly important part of the Australia-US relationship. These developments made Richardson, with his decade at the head of ASIO as well as his diplomatic experience, an ideal candidate to head the Australian mission in Washington.

Richardson's tenure as head of mission in Washington straddled the last years of the Howard Liberal-National Party Government and the first two years of a Labor administration under Kevin Rudd. Richardson was Ambassador during a time when a number of aspects of Australia-US relations were becoming a source of controversy in Australia. By 2006 the allied occupation of Iraq was going badly, and the abuse and torture of prisoners at Abu Ghraib and Guantánamo Bay becoming a source of increasing public concern. ${ }^{14}$ Of particular worry to many Australians was the detention by US authorities of the South Australian, David Hicks, who had been captured by the US military in Afghanistan in 2001 and detained in Guantánamo Bay but was only released into Australian custody in April 2007. The Cole Inquiry hearings conducted in 2006 were also a source of embarrassment to the Australian Government. These hearings established that the Australian Wheat Board had diverted money to the Iraqi regime of Saddam Hussein during the management of the UN oil-for-food program. Richardson and the embassy in Washington helped the Howard Government manage such thorny problems in the bilateral relationship. These issues were leavened, however, by the celebration of an important milestone in the bilateral relationship. Richardson was head of mission during the centenary celebrations of the 1908 visit of the United States Navy (the 'Great White Fleet') to Australia.

Late in 2007 a Labor Government was elected in Australia and in November 2008 the Democrat Barack Obama was elected President of the United States of America. Possessing a broad range of contacts across the political divide in Washington, Richardson smoothly managed

14 James Cotton, 'Australia-America 2006-2010: Waiting for Obama', in James Cotton and John Ravenhill (eds), Middle Power Dreaming: Australia in World Affairs 2006-2010, Oxford University Press, Melbourne, 2012, p. 54. 
the implications of the changes of government in both Australia and the United States. The periods in office of Rudd and Obama from 2009 heralded a new era of policy convergence in the Australia-US relationship. Both Rudd and Obama had opposed the allied invasion of Iraq in 2003; and both were outspoken about the need for international collaboration to address the anthropogenic causes of climate change. Richardson and the embassy coordinated Rudd's first visit to Washington in March 2009 where the two leaders discussed the need for international palliative measures to address the Global Financial Crisis, including Rudd's ambitious reform plans for the G20 group of nations. The Obama Administration also welcomed the Rudd Government's establishment, with Japan, of the International Commission on Nuclear Non-Proliferation and Disarmament, whose brief was to devise measures to strengthen the nuclear non-proliferation regime. The institutionalised, high-level consultations known as Australia-US ministerial consultations took place in Canberra in February 2008 and in Washington in April 2009, the latter meeting assisted by Richardson and the Australian embassy in Washington. Richardson completed a distinguished term as Australian Ambassador to the US in September 2010 before commencing a period as Secretary of the Department of Foreign Affairs and Trade.

Richardson was succeeded by a political appointee, Kim Beazley, who provides an invaluable reflection, including on his own period as Ambassador, in this volume. Kim Christian Beazley was born in Western Australia on 14 December 1948, the son of Kim Edward Beazley, a federal Labor Member of Parliament and Minister for Education between 1972 and 1975. The younger Beazley was educated at the University of Western Australia and then Oxford University. A tutor and then lecturer in social and political theory at Murdoch University in the years after 1976, Beazley was elected to the federal parliament for the seat of Swan in 1980. With the election of the Hawke Government in 1983, he became the Minister for Aviation from 1983 to 1984, assisting the Minister for Defence. He was Minister for Defence between 1984 and 1990 and oversaw major changes in the portfolio following the landmark 1987 Defence White Paper. As Minister for Defence, Beazley was also an important participant in navigating the ANZUS crisis of 1984 to 1986 . He was Minister for Transport and Communications from 1990 to 1991, Minister for Finance in 1991, Minister for Employment, Education and Training from 1991 to 1993, and Minister for Finance again from 1993 to 1996. Following the 
defeat of the Keating Government in 1996, Beazley became leader of the opposition and came within a few seats of defeating the Howard Government in 1998 but lost more decisively in 2001. After an interlude in which Simon Crean and then Mark Latham led the ALP federal Opposition, Beazley once again held that position between January 2005 and December 2006 before being replaced by Rudd, who went on to defeat Howard at the 2007 federal election. After Richardson's appointment as Secretary of the Department of Foreign Affairs and Trade in 2009, Rudd appointed Beazley Ambassador to the United States, a position that Beazley would occupy with great distinction from 2010 to 2016.

Beazley was one of the best-connected of any of Australia's ambassadors when he arrived in Washington. Like Cotton, Beazley's credentials were respected on both sides of politics, as was reflected by the Abbott Government's decision to extend his term. Beazley had excellent contacts on both sides of the political divide in Washington. He knew many of the top Republican leadership from his time in Australian politics in the 1980s and 1990s, and he proved to be a most popular envoy with the Obama Administration. Beazley's longstanding acquaintance with the US, detailed knowledge of American history and his skill as an analyst of international affairs and Australian politics earned him the respect of Obama and his Secretary of State, John Kerry. This was demonstrated on 13 October 2015 when Beazley hosted Kerry among others at a reception in Washington to celebrate 75 years of friendship between Australia and the United States, and by the warmth of Kerry's remarks on Beazley's departure from Washington. ${ }^{15}$

Beazley's retrospective essay in this volume covers the whole period from 1940. He notes that when he commenced in Washington, the embassy was Australia's second-biggest, after Indonesia, and that after the integration of the Department of Foreign Affairs and Trade with AusAID in 2014, it had dropped to third after Jakarta and Port Moresby. It remains, nonetheless, one of Australia's most important overseas missions with its 93 Australia-based and 176 locally engaged staff and a centrally located chancery and Ambassador's Residence that provide an ideal basis for cultural and public diplomacy activities.

15 'Kim Beazley's US ambassador stint comes to an end', SBS, 21 January 2016. 
Australian ambassadors to the US in the early 21st century understandably do not have the same access to the US Administration that Casey, Makin and Spender had in the much smaller Washington of the 1940s and 1950s. In contrast to a time when ambassadors had readier access to Presidents and Secretaries of State, a critical part of the ambassador's and embassy's work in the 21st century is in supporting and enabling prime ministerial and ministerial visits. But aside from consular activities, an essential part of the embassy's work, Beazley argues, is the vital task of political reporting. The salience of this was marked particularly by the creation in the 1990s of the embassy's Congressional branch. Relations with members of Congress themselves remain with the ambassador, largely because he or she is the only one that senators or members of Congress will agree to see. While formal diplomatic relations between Australia and the US began in the cauldron of World War II and with Australia and the US under threat from Japan, Beazley concludes, nevertheless, that American priorities have never been more important to Australia and that Australia is a more significant ally geographically than at any time since World War II. In this context, Australia's embassy in Washington, after 75 years, remains one of its most important.

In 2016 Joseph Benedict 'Joe' Hockey was appointed to succeed Beazley. Like the first head of mission in Washington, Casey, Hockey was a former federal Treasurer and aspirant to leadership of the Liberal Party. Born in Sydney on 2 August 1965 to an Armenian father and Australian mother, Hockey attended St Aloysius College, Milsons Point, and then the University of Sydney from which he graduated with a Bachelor of Arts and Bachelor of Laws. Elected as a Liberal for the seat of North Sydney in 1996, he was appointed by John Howard as Minister for Financial Services and Regulation from 1998 to 2001 and Minister for Small Business and Tourism from 2001 to 2004, then Minister for Human Services from 2004 to 2007, and Minister for Employment and Workplace Relations in 2007.

During the period of the Labor Government after 2007, Hockey held a number of senior front-bench positions before being elevated to the position of Shadow Treasurer in 2009. In December 2009, Hockey contested the leadership of the Liberal Party with Malcolm Turnbull and Tony Abbott but was eliminated in the first round of voting in the ballot that Abbott won. After the defeat of the Rudd Government in 2013, Hockey was Federal Treasurer in the government led by Tony 
Abbott. On Abbott's replacement as prime minister by Malcolm Turnbull, Hockey resigned from parliament in October 2015, and on 8 December of that year it was announced that Hockey would replace Beazley as Ambassador to the US. Hockey's ambassadorship during a time of another hard-fought US election awaits the attention of future historians. 
This text is taken from Australia goes to Washington: 75 years of Australian representation in the United States, edited by David Lowe, David Lee and Carl Bridge, published 2016 by ANU Press, The Australian National University, Canberra, Australia. 